\title{
A Critical Analysis of Relationship between Gold Prices and NEPSE Index
}

\author{
Nischal Risal \\ Lecturer, Nepal Commerce Campus, T.U.
}

\begin{abstract}
The investors' prioritization towards the gold investment and capital market investment is really interesting issue. To clear the issue in the context of Nepal, the research paper seeks the relationship between gold prices on Nepalese capital market. The descriptive and analytical research design has been adopted in the study. The study is based on quantitative approach. The data has been collected from July 2015 to July 2018. The information on market index and gold price has been collected for the same period. The information has been collected from the annual reports of NEPSE, Nepal Gem and Jewellery Association (NEGJA), Nepal gold market and Federation of Nepal Gold and Silver Dealer's Association (FENEGOSIDA). The comparative analyses of gold market and capital market have shown the direct relationship between these two markets. The investors' tendency to switch to gold investment is found risky. The gold prices and interest rates have influence on NEPSE.
\end{abstract}

Keywords: Market index; Equity index; Gold prices; Interest rates; Capital market

\section{Introduction}

The investors have an option to invest in capital market securities as well as gold market. The capital market and gold market are two complementary investment opportunities. The investors can invest in either securities or both based on the risk, return and time factor.The precious metal gold value is also determined by interest rates and the presence of lucrative alternative investment avenues in the economy. Gold price is included in the study to examine whether gold price contain any additional significant information about price movements. Stock market is at its optimal when the stock prices move in accordance with the fundamentals. In such a situation, a firm can also raise the required capital at optimal cost. As a result, the stock market of Nepal measured and indicated by NEPSE (Nepal Stock Exchange) has experienced many ups and downs during its long journey. There are many factors which affect the stock prices and in turn the overall index. The influence of gold prices on NEPSE, the effects of NRB policy on gold in NEPSE, gold smuggling and NEPSE are the major research issues. Thus, the study aims to assess the relationship between gold prices on Nepalese capital market.

\section{Methods}

The descriptive and analytical research designs have been adopted in the study. The study is quantitative as relationship is examined by expressing variables in measurable terms. The published information is used for analysis and interpretation. The thematic research paper is based on the review and secondary information obtained from international and national magazines, newspaper, journals, books and 
annual reports. The study has made an attempt to model the yearly, monthly and daily reports of NEPSE and gold prices. The information related to market index and gold price movements have been collected from July 2015 to July 2018. The MS Excel software has been used to tabulate and analyze the data.

\section{Thematic Analysis}

Ross (1976) established the theoretical framework to link stock returns with several variables which could influence the source of income volatility (Rahman and Tafri 2009). Higher interest might reduce the tendency of investors to borrow, invested in stocks, and raised the cost of doing business that had affected profit margin. The lower interest rates from expansionary monetary policy had boosted the stock market (Fama, 1981; Geske and Roll, 1983) and contrary to Chia and Lim (2015) revealed the positive relation. Chaudhuri and Koo (2001) found that both domestic macroeconomic variables and international variables had significant impact on stock return volatility. The role of government in terms of fiscal and monetary policy in smooth functioning of the stock market was crucial. Sharma and Mandeep (2010) evaluated the long term relationship between Bombay Stock Exchange (BSE) and Macro-economic variables; exchange rates, interest rate, foreign exchange reserve, inflation rate and gold price. The domestic and international gold prices were co-integrated with the Indian stock indices.

In Nepali context, Baskota (2007) concluded that there was no persistence of volatility in Nepalese stock market and the stock price movements were not explained by the macroeconomic variables. Shrestha and Subedi (2014) found the positive relationship with inflation, money supply growth and interest rates. However, very few studies had touched upon the issues of scientific analysis and forecasting of stock index as well as price of the companies. Therefore, development and testing of scientific models and tools for forecasting and prediction of stock indices and price of the companies become essential. Gaire (2018) concluded that there was long run equilibrium relationship between the NEPSE index, short term interest rates and gold prices in Nepal. There was unilateral causal relationship between the NEPSE index and short term interest rate which moved from interest rate to NEPSE index. The short-term interest rates are the better predictor for NEPSE index and bullion (commodity) market was yet to be developed as substitute of the stock market. Risal (2016) had also explained the scenario and the importance of capital market development in Nepal. In addition, Risal and Khatiwada (2019) had explained the herding behavior in Nepalese capital market. The result had revealed the significant relationship of hasty decision with herd behavior. Thus, the study focused towards the investors' preferences on capital market as well as gold market in Nepal.

\section{Etymological Dimension}

\section{History of Stock Exchange}

The history of the capital market began in early 17th century with the Amsterdam Stock Exchange (1602) in The Netherlands, followed by Paris Bourse (1724) in France, Philadelphia Stock Exchange (1790) in USA, London Stock Exchange (1801) in England, Milan Stock Exchange (1808) in Italy, New York Stock Exchange (1817) in USA, Frankfurt Stock Exchange (1820) in Germany, Bolsa de Madrid (1831) in Spain, Toronto Stock Exchange (1861) in Canada, and Australian Stock Exchange (1872) in Australia which were the oldest ten stock exchanges in the world. Bombay Stock Exchange (BSE) was the first stock exchange, not only in India but also in Asia, established in 1875. Tokyo Stock Exchange was established in 1878. The history of securities market began with the floatation of shares by Biratnagar Jute Mills Ltd., and Nepal Bank Ltd., in 1937. Introduction of the Company Act in 1964, the first issuance of Government Bond in 1964 and the establishment of Securities Exchange Center Ltd. in 1976 were other significant development relating to capital markets. Securities Exchange Center was established with an objective of facilitating and promoting the growth of capital markets. Before conversion into stock exchange it was the only capital market institution undertaking the job of brokering, underwriting, managing public issue, market making for government bonds and other financial services. NEPSE is established under the Companies Act 2006, operating under Securities Act 2007. 
The basic objective of NEPSE is to impart free marketability and liquidity to the government and corporate securities by facilitating transactions in its trading floor through member, market intermediaries, such as broker, market makers etc. NEPSE opened its trading floor on13th January 1994. The history of securities market had began with the floatation of shares by Biratnagar Jute Mills Ltd. and Nepal Bank Ltd. in 1937. An introduction of the Company Act, 1964, the first issuance of Government Bond 1964 and the establishment of Securities Exchange Center Ltd., 1976 were other significant development relating to capital markets. The Securities Exchange Center was had the objective of facilitating and promoting the growth of capital markets. The center was only the capital markets institution undertaking the job of brokering, underwriting, managing public issue, market making for government bonds and other financial services. Under financial sector reform program, the market had reformed to Securities Exchange Center into Nepal Stock Exchange in 1993. Nepal Government, under a program initiated to reform capital markets converted Securities Exchange Center into Nepal Stock Exchange in 1993. NEPSE started its trading floor on the 13th January 1994 with the index value of 100 points. After its establishment, banking and finance, insurance, manufacturing and service, and hydropower companies have gradually started to list their common stocks for trading. Since then investors are blindly following NEPSE Index to know about the market trend. As on 13th September 2018, there are 59 stock brokers and 210 listed companies. The return on stocks is highly sensitive to both fundamentals and expectations. The latter in turn is influenced by the fundamentals which may be based on either rational or adaptive expectation models. The inception of the capital market has provided abundant investment opportunities to the individuals and the institutional investors in Nepal (NEPSE Annual Reports).

\section{History of Gold}

Gold was first discovered as shining, yellow nuggets. 'Gold is where you find it,' so the saying goes, and gold was first discovered in its natural state, in streams all over the world. No doubt it was the first metal known to early hominids. Gold was money in ancient Greece. The Greeks mined for gold throughout the Mediterranean and Middle East regions by 550 B.C., and both Plato and Aristotle wrote about gold and had theories about its origins. Gold was associated with water (logical, since most of it was found in streams), and it was supposed that gold was a particularly dense combination of water and sunlight. While investment demand is important, the largest use for gold is in jewelry, with the majority of use occurring in the United States, Japan, Italy, India, China, and Thailand. Jewelry production has been growing at a robust pace in the developing countries of Southeast Asia and the Middle East since 1988. Gold also is used in electronic connectors and dental alloys. Actually the history of gold in the derivative market had been turned since the twentieth century when it was pegged to currencies as a standard of foreign exchange dealing. Traders had been always fascinated by the gold since it was the symbol for purity, value, royalty, wealth and prestige. Indeed, gold traditionally has served three functions: as a monetary instrument, as a financial asset, and as a raw material primarily used in jewelry and decorative objects. In order to access the relationship between gold (commodity) market and capital market in Nepal, end of months gold prices (per 10 gram) have been used. The source of gold prices for the study was Nepal Gold and Silver Dealers Association (NEGOSIDA). Economists said that the unproductive import of commodities like gold only worsened the trade deficit of the country which was widening at the high pace. Bullion had become safe collateral for banks to float loans. Financial institutions had provided gold and silver loans at approximately ten percent to twenty percent interest rate, while informally money lenders had charged up to approximately 36 percent interest for such informal lending. Though NRB forbids anyone except licensed financial institutions that had obtained permission to issue gold or silver loans to lend against gold collateral, there were lots of money lenders and even jewelers engaged in such dealings.

\section{Ontological Dimension}

Gold was considered as one of the safe investment vehicles and used for hedging against the price 
risk across the world. Gold price movements were determined by the perception of gold as a 'store of value' rather than its fundamentals as a commodity. The precious metal's value was determined by such factors as inflation, interest rates and the presence of lucrative alternative investment avenues in the economy. Gold on many international markets was priced in US Dollars. So, if the value of the dollar went down, it would take more dollars to buy an ounce of gold. The real estate charm in the country had decreased after devastating 2015 earthquake. People didn't want to own luxurious things like gold. As the result, loan rates had decreased followed by low fixed deposit rate and that made both banking and real estate sector unattractive for the investor. The capital started flowing in the stock market which took NEPSE to reach bullish on all-time high of 1,881.45 points in 27th July 2016, comparing with gold price Rs 46,200 and interest rate of 3.28 percent on the same month. The total turnover of the day stood above Rs 2 billion, where more than 4.8 billion unit shares were traded through 10,793 transactions. As on 15th June 2011, NEPSE reached bearish on 292.31 points where the gold price was Rs 34,600 and interest rate was 10.23 percent on the same month. Bank had earned profit mainly from the interest on loan. Fixed deposits were considered safe than stock market. Many investors who were involved in market with the loans had gone bankrupt and the one who had survived were definitely not looking to stay longer as interest rates on loans were soaring and the market return was very low. Thus, these factors were building negative sentiment in people towards stock market. As per the monetary policy 2075/76, banks' interest spread rate was limited to 4.5 percent. The group-wise distribution of market capitalization was shown in figure 1 . The chart had explained that the commercial bank had occupied 52 percentages, insurance companies had occupied 15 percentages, finance companies had 10 percentages, and microfinance institutions had occupied seven percentages followed by hydropower companies, development banks, manufacturing and processing companies, trading, and others. It had indicated that the market capitalization had been dominated by commercial banks in Nepal.

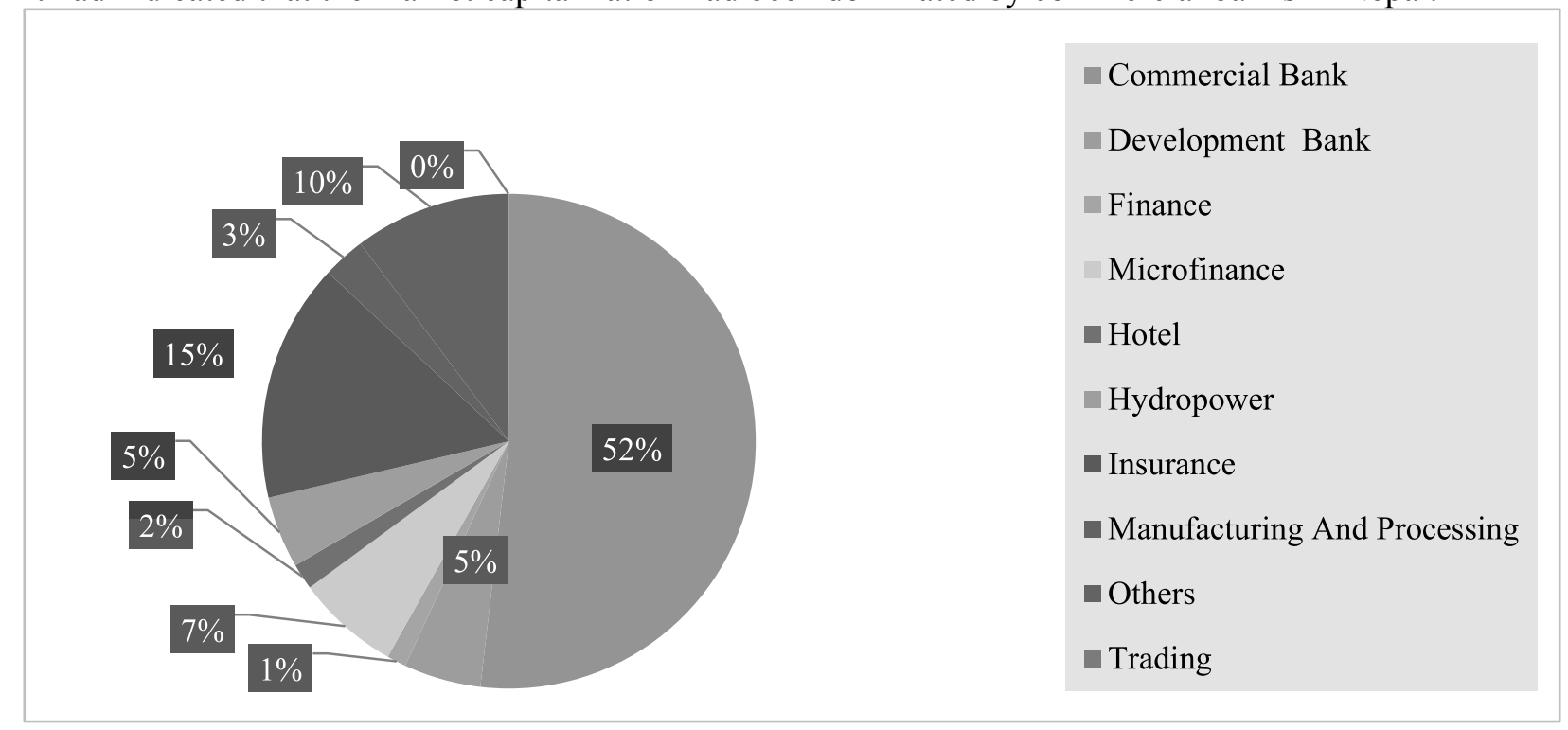

Figure 1 Group-wise Distribution of Market Capitalization (Source: NEPSE Annual Reports)

The summary sheet of NEPSE from the date 17th July 2015 to 16th July 2018 in the Table 1 had shown the share units, amount, and change during the years in NEPSE. The data analysis had shown that the trading of shares was increased from the year 2015 July to July 2017 whereas decreased from July 2017 to July 2018. It had indicated fluctuating trend in turnover. While analyzing the share units, amount of commercial banks, development banks, finance companies and microfinance institutions, it had been noticed traded volume was positive during the period from 2015 July to 2017 July and positive change had been observed whereas from July 2017 onwards to July 2018 the change was found negative. 
Table 1

Summary Sheet NEPSE

\begin{tabular}{|c|c|c|c|c|c|c|c|c|c|}
\hline \multirow{3}{*}{$\begin{array}{l}\mathrm{S} \\
\mathrm{N}\end{array}$} & \multirow{3}{*}{ Particulars } & \multicolumn{2}{|c|}{$\begin{array}{c}\text { 17-Jul-2015 To 15- } \\
\text { Jul-2016 }\end{array}$} & \multicolumn{2}{|c|}{$\begin{array}{c}\text { 16-Jul-2016 To 15- } \\
\text { Jul-2017 }\end{array}$} & \multirow[t]{2}{*}{ Chg } & \multicolumn{2}{|c|}{$\begin{array}{c}\text { 16-Jul-2017 To 16- } \\
\text { Jul-2018 }\end{array}$} & \multirow[t]{2}{*}{ Chg } \\
\hline & & $\begin{array}{l}\text { Share } \\
\text { units }\end{array}$ & Amt & $\begin{array}{l}\text { Share } \\
\text { units }\end{array}$ & Amt & & $\begin{array}{l}\text { Share } \\
\text { units }\end{array}$ & Amt & \\
\hline & & ('000) & $\begin{array}{l}\text { Rs. in } \\
\text { Million }\end{array}$ & ('000) & $\begin{array}{l}\text { Rs. in } \\
\text { Million }\end{array}$ & $\%$ & ('000) & $\begin{array}{l}\text { Rs. in } \\
\text { Million }\end{array}$ & $\%$ \\
\hline 1 & Turnover & 303575.2 & 164651.7 & 392881.5 & 205023.2 & 24.52 & 293817.5 & 121391.0 & -40.79 \\
\hline 2 & $\begin{array}{l}\text { Commercial } \\
\text { Banks }\end{array}$ & 95923.65 & 70771.92 & 137144.47 & 95220.27 & 34.55 & 106733.82 & 41800.28 & -56.1 \\
\hline 3 & $\begin{array}{l}\text { Development } \\
\text { Banks }\end{array}$ & 38026.23 & 24942.86 & 38047.98 & 28125.15 & 12.76 & 27661.93 & 14123.87 & -49.78 \\
\hline 4 & Finance & 12649.32 & 4578.98 & 11212.97 & 5595.09 & 22.19 & 7054.18 & 2220.95 & -60.31 \\
\hline 5 & Hotels & 3208.20 & 1116.37 & 4112.64 & 1592.52 & 42.65 & 3511.57 & 1408.32 & -11.57 \\
\hline 6 & Hydro Power & 24953.93 & 10185.65 & 17918.72 & 7697.76 & -24.43 & 22580.28 & 8395.03 & 9.06 \\
\hline 7 & $\begin{array}{l}\text { Manufacturing \& } \\
\text { Processing }\end{array}$ & 23.45 & 232.06 & 794.18 & 396.27 & 70.76 & 161.23 & 558.40 & 40.91 \\
\hline 8 & Microfinance & & & & & & 8980.51 & 10114.34 & \\
\hline 9 & Mutual Fund & 80330.50 & 1113.71 & 125488.63 & 1886.92 & 69.43 & 62693.71 & 942.62 & -50.04 \\
\hline 10 & $\begin{array}{l}\text { Non Life } \\
\text { Insurance }\end{array}$ & 25727.70 & 38985.07 & 28137.23 & 50817.03 & 30.35 & 22067.04 & 27504.85 & -45.87 \\
\hline 11 & Others & 1502.00 & 904.78 & 6824.90 & 2717.81 & 200.38 & 5678.08 & 3318.05 & 22.09 \\
\hline 12 & $\begin{array}{l}\text { NEPSE Index } \\
\text { High }\end{array}$ & & 1724.59 & & 1881.45 & 9.1 & & 1667.94 & -11.35 \\
\hline 13 & $\begin{array}{l}\text { NEPSE Index } \\
\text { Low }\end{array}$ & & 961.23 & & 1252.50 & 30.3 & & 1168.55 & -6.7 \\
\hline 14 & $\begin{array}{l}\text { NEPSE Index } \\
\text { Closing } \\
\text { NEPSE }\end{array}$ & & 1718.15 & & 1582.67 & -7.89 & & 1212.36 & -23.4 \\
\hline 15 & $\begin{array}{l}\text { Sensitive Index } \\
\text { High } \\
\text { NEPSE }\end{array}$ & & 373.05 & & 405.23 & 8.63 & & 350.18 & -13.58 \\
\hline 16 & $\begin{array}{l}\text { Sensitive Index } \\
\text { Low } \\
\text { NEPSE }\end{array}$ & & 204.67 & & 271.77 & 32.78 & & 248.03 & -8.74 \\
\hline 17 & $\begin{array}{l}\text { Sensitive Index } \\
\text { Closing }\end{array}$ & & 369.07 & & 336.04 & -8.95 & & 255.20 & -24.06 \\
\hline 18 & $\begin{array}{l}\text { NEPSE Float } \\
\text { Index High }\end{array}$ & & 125.66 & & 139.95 & 11.37 & & 121.40 & -13.25 \\
\hline 19 & $\begin{array}{l}\text { NEPSE Float } \\
\text { Index Low }\end{array}$ & & 68.47 & & 92.36 & 34.89 & & 83.98 & -9.07 \\
\hline 20 & $\begin{array}{l}\text { NEPSE Float } \\
\text { Index Closing }\end{array}$ & & 125.41 & & 116.14 & -7.39 & & 87.15 & -24.96 \\
\hline
\end{tabular}

(Source: NEPSE Annual Reports) 
The highest change was found in finance companies, followed by commercial banks, development banks and microfinance institutions. It had indicated that the effect was more in commercial banks during the stated period. The capital market of trading companies, mutual fund and non life insurance companies were also found mostly effected where as less effect was found in hydropower and hotels. NEPSE index was found decreased in the given periods. In the middle of 2018 the data had explored the negative change in NEPSE index. NEPSE index was found in decreasing trend from approximately 1600 index to approximately 1100 as shown in Figure 2. It had indicated that the reasons for such decrease in market index should be determined and analyzed accordingly. The last ten years index trend analysis had shown the fluctuating trend of NEPSE as shown in Figure 3. The trend analysis had indicated the expectation of positive change in NEPSE index in 2020/21 year. The changes in group wise index for the fiscal year 2017/18 had been shown in Table 2.

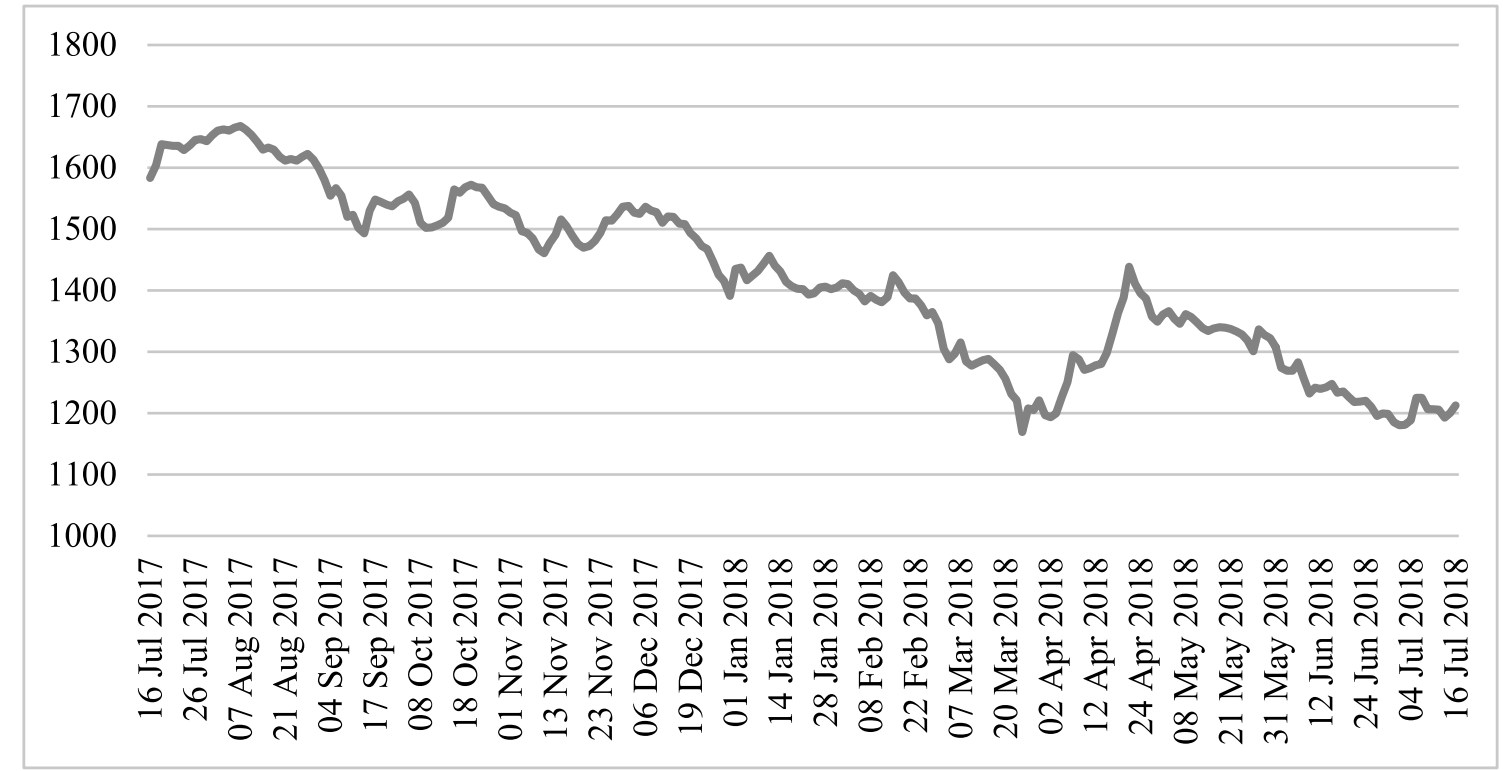

Figure 2 NEPSE Index in the Fiscal Year 2017/18 (Source: NEPSE Annual Reports)

The highest change in market index was found in commercial banks, followed by development banks, insurance, hydropower, finance, hotel and others. The huge change in market index during the short period had created huge amount of loss and profit for the investor.

Table 2

Change in Group-Wise Index in Respect to Starting of the FY 2017/18

\begin{tabular}{llccc}
\hline S.N & Group & Opening Index & Closing Index & Chg \% \\
\hline 1 & Commercial Bank & 1421.22 & 1023.56 & -27.98 \\
2 & Development Bank & 1944.93 & 1434.16 & -26.26 \\
3 & Finance & 740.55 & 605.67 & -18.21 \\
4 & Microfinance & & 1607.08 & \\
5 & Hotel & 2215.75 & 1846.72 & -16.65 \\
6 & Hydropower & 1909.1 & 1498.13 & -21.53 \\
7 & Insurance & 8351.77 & 6199.45 & -25.77 \\
8 & Manufacturing \& & 2366.37 & 2264.14 & -4.32 \\
9 & Processing & & & 1.98 \\
10 & Orading & 694.12 & 707.89 & -7.75 \\
\hline
\end{tabular}

(Source: NEPSE Annual Reports) 


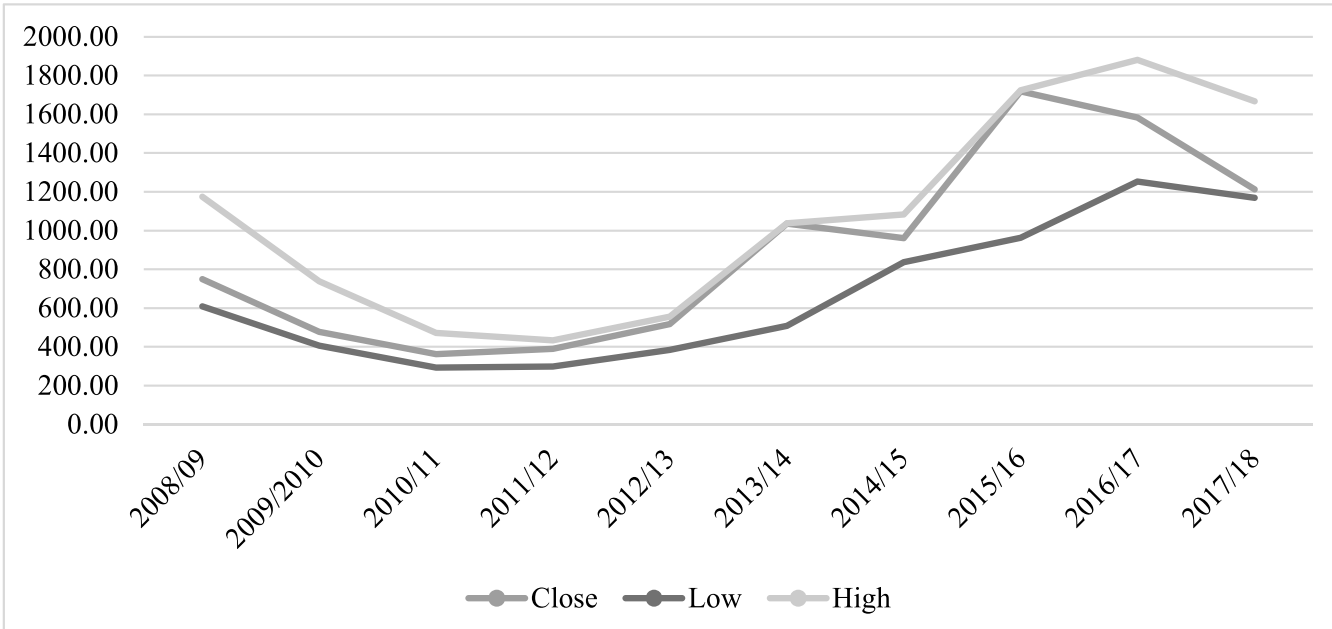

Figure 3 Last Ten Year's NEPSE Index

\section{Gold Price Movements}

The NEPSE indexes from the fiscal year 2072/73 to fiscal year 2074/75 had been extracted and analyzed the changes, pattern and trend of movement of stock prices. In the same period, the price of gold had been shown in the Table 3. The bullion gold prices have found to increase massively during these periods.

Table 3

Gold Price in Nepal during the fiscal year

\begin{tabular}{|c|c|c|c|}
\hline Date & $\begin{array}{l}\text { Hallmark Gold Average Prices } \\
\text { Per Tola (11.6638 gms) (in Rs) }\end{array}$ & Date & $\begin{array}{c}\text { Hallmark Gold Average Prices } \\
\text { Per Tola (11.6638 gms) } \\
\text { (in Rs) }\end{array}$ \\
\hline July, 2015 & 47974 & January, 2017 & 54600 \\
\hline August, 2015 & 49754 & February, 2017 & 54600 \\
\hline September, 2015 & 50244 & March , 2017 & 54600 \\
\hline October, 2015 & 50478 & April , 2017 & 55234 \\
\hline November, 2015 & 48883 & May, 2017 & 54234 \\
\hline December, 2015 & 48472 & June, 2017 & 54450 \\
\hline January, 2016 & 48990 & July, 2017 & 53200 \\
\hline February, 2016 & 51500 & August, 2017 & 55200 \\
\hline March , 2016 & 56280 & September, 2017 & 48787 \\
\hline April , 2016 & 54634 & October, 2017 & 48055 \\
\hline May, 2016 & 56600 & November, 2017 & 47919 \\
\hline June, 2016 & 56720 & December, 2017 & 47020 \\
\hline July, 2016 & 58883 & January, 2018 & 48758 \\
\hline August, 2016 & 59071 & February, 2018 & 49275 \\
\hline September, 2016 & 58600 & March , 2018 & 58300 \\
\hline October, 2016 & 56800 & April , 2018 & 57900 \\
\hline November, 2016 & 55300 & May, 2018 & 59000 \\
\hline \multirow[t]{2}{*}{ December, 2016} & 52517 & June, 2018 & 49989 \\
\hline & & July, 2018 & 56833 \\
\hline
\end{tabular}


Table 3 had shown that the average price of hallmark gold during the study period was found to be Rs 53234 per tola. The gold price Rs 59071was highest in August, 2016 and lowest price Rs 47020 was in December, 2017. The trend of gold price was not found much fluctuating as shown in Figure 4. Table 3 and Figure 4 had shown that at the end of 2017, the gold price was decreased whereas increased in the middle of 2016. The September and October, 2016 become the great period for gold selling. The gold prices had remained somehow constant in 2017 but started to increase from 2018 onwards. The price of gold per tola was Rs 61000 in May 16, 2019; Rs 65000 in 21 June, 2019; Rs 70000 in 8 August, 2019. The hallmark gold price per tola in 29th September is Rs 70200 per tola. Gold price had been significantly increased up in the recent period. Usually, there was the direct relationship between American Dollar and gold rate. The price of gold had been found to increase with increase in monetary value of USA Dollars. Similarly, the gold price had increased with decrease in price of crude oil in global market.

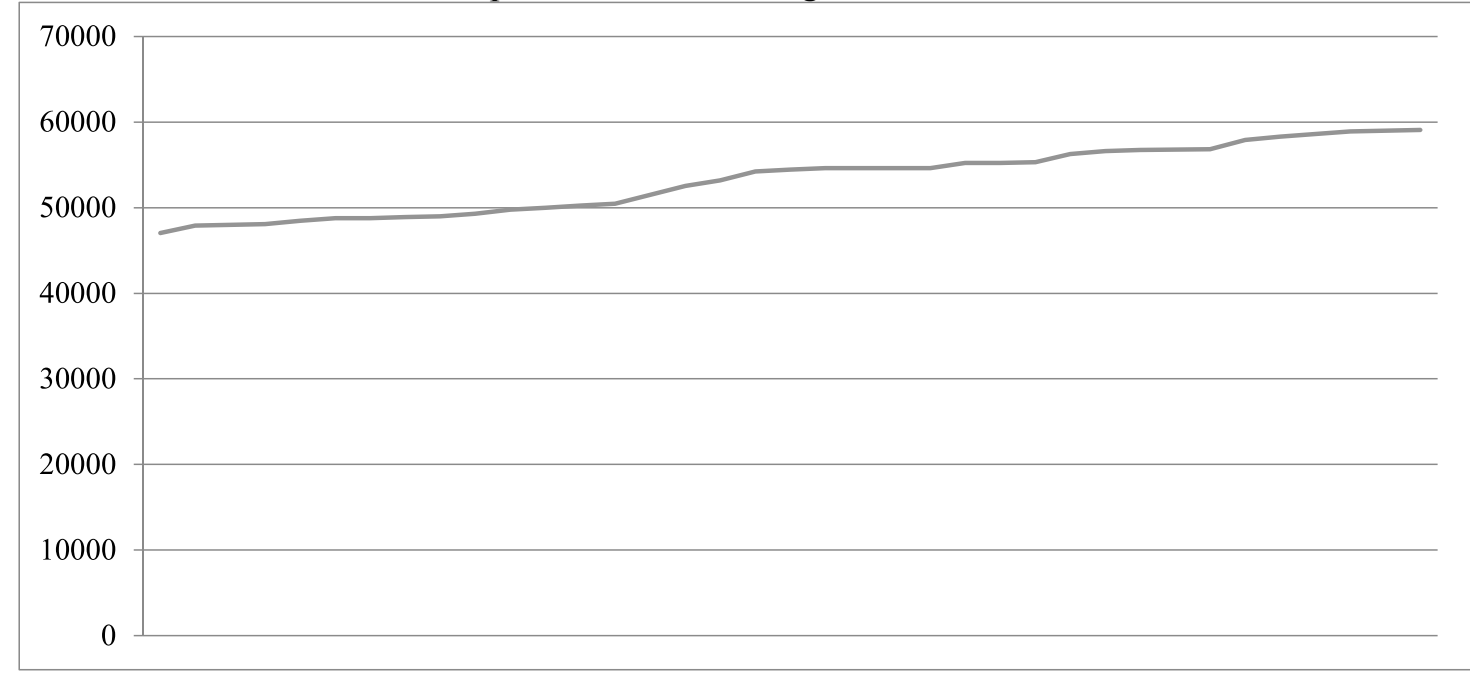

Figure 4 Trend Analysis of Hallmark Gold Price Movements in Nepal

The price of gold and silver in Nepal was fixed by Federation of Nepal Gold and Silver Dealers' Association. The bullion rate was fallen sharply after tragic earthquake. The major causes were lowering rate of gold in international market and lowering in import tax of gold by Nepal government. Inversely, the gold price had risen up due to new tax provision of government, international market, fluctuation in dollar price and so on. The gold price had been increasing in the increasing rate globally from 2015 to 2018 as shown in Table 4. The price per ounce of hallmark gold was 1096.3 US Dollars in 2015 which had been increased to 1495.9 in the year 2018. Thus, the comparative analysis of gold market and capital market had shown that the direct relationship between gold market and capital market. However, in depth analysis was needed to come up with concrete conclusion. Because, in 2019, the observation had shown that market index was in decreasing trend, whereas gold prices was in increasing trend.

Table 4: Gold Prices in a Globe (Per Ounce $=28.3495 \mathrm{gms}$ )

\begin{tabular}{ccccccc}
\hline Year & USD & EUR & JPY & CHF & AUD & INR \\
\hline 2015 & 1096.3 & 1015.2 & 130213 & 1113.6 & 1565.4 & 74083.4 \\
2016 & 1159.10 & 1001.6 & 135556 & 1179.7 & 1606.7 & 78753.9 \\
2017 & 1296.5 & 1082.5 & 146004 & 1262.9 & 1658.5 & 82755.6 \\
2018 & 1495.9 & 1367.2 & 161497.4 & 1482.2 & 2211.3 & 105693 \\
\hline
\end{tabular}

(Source: goldpriceoz.com)

\section{Epistemology Dimension}

Market index is the pure statistical numbers that measures the movement of stock prices in two 
distinct periods. The market index is generally calculated using price weighted index, equally weighted index and value weighted index. NEPSE calculate the market index based on value weighted method. The concept can be illustrated with a hypothetical example, considering ' 0 ' as the base period and ' 1 ' as the current period as follows:

Table 5

Value Weighted Index Calculation

\begin{tabular}{|c|c|c|c|c|c|}
\hline \multirow{2}{*}{ Company } & \multirow{2}{*}{$\begin{array}{c}\text { Outstanding } \\
\text { Shares }\end{array}$} & \multicolumn{2}{|c|}{ Closing Price } & \multirow{2}{*}{$\begin{array}{c}\text { Market Capitalization } \\
\text { At ' } 0 \text { ' time }\end{array}$} & \multirow{2}{*}{$\begin{array}{c}\text { Market Capitalization } \\
\text { At '1' time }\end{array}$} \\
\hline & & At '0' time & At ' 1 ' time & & \\
\hline $\mathrm{X}$ & 1000 & 50 & 55 & 50000 & 55000 \\
\hline Y & 2000 & 60 & 70 & 120000 & 140000 \\
\hline Z & 3000 & 70 & 75 & 210000 & 225000 \\
\hline \multicolumn{4}{|c|}{ Total market Capitalization (Total Market Value) } & 380000 & 420000 \\
\hline
\end{tabular}

NEPSE Index $=\frac{\text { Total Market Capitalization of all the Companies Listed }}{\text { Total Base Year's Market Capitalization }} * 100$

NEPSE Index for the time period ' 1 ' is 110.526 with reference to the base period ' 0 '. It had indicated the movement of share price by 10.526 up in relation with previous days' price. It had signaled positive information to the shareholders.

\section{Capital Market versus Gold Market in Nepal}

Compared with the Western economy, NEPSE has not been able to attract more listings due to various economic and political hurdles. But, the practice of exchanging financial instruments through the organized stock exchange is a recent development in Nepal whereas the developed countries have their long history of the practice. Many private companies don't want to go public. The valuation of promoter and government shares are based on latest market price which is not a true valuation. Sometimes the company publishes incomplete and misleading financials intentionally showing that they are in loss, debt is very high, loans are not recovering etc. These financials create negative sentiment in public as a result they start to sell their stakes. This lowers the stock price, after which top-level staffs start buying the stock at low prices. When they find a supply for the stock has reached a maximum, they publish a very positive and logical argument for future growth.

NEPSE does not represent the medium and small size companies. Banking sectors has dominated the stock market. Determination of interest rate has a major role in banking sectors to meet their paid-up capital. When interest rate rises, there is dual effect which can affect stock market negatively. One is riskaverter investors exists market and move for safer investment fixed deposit and trader or speculator who are using bank money for investment also tries to exist market since bank now charges higher interest rate on loan. Stock brokers are still handling paper works and placing their orders for trading. They are not able to give priority to all customers equally; beginners, small, medium and big investors. The timing is considered the most valuable for the investors. The online trading which was said to start from first date of Shrawn 2075 is in progressive phase.

NRB had been receiving complaints that some middlemen are taking bullion as collateral and floating loans, and then again borrowing from financial institutions by keeping the same ornaments as collateral. Commercial banks, the only authorized institutions struggle to sell even $20 \mathrm{~kg}$ of gold that they import. They blame the supply of gold through illegal channel for low demand of gold imported by them. Tribhuvan International airport (TIA) and Rasuwagadhi are the major points for gold smuggling. Smugglers seemed to have turned to Rasuwagadhi from Tatopani route was shut down after 2015 earthquake. Every year market declines in between Dashain and Tihar festival as investors need more liquid cash in hand for festive 
purpose. This period of time is also taken as 'Wait and Watch' period.

Gold is a rare metallic element with a melting point of 1064 degrees centigrade and a boiling point of 2808 degrees centigrade. Its chemical symbol is ' $\mathrm{Au}^{\prime}$. It has several properties that have made it very useful to mankind over the years, notably its excellent conductive properties and its inability to react with water or oxygen. 'Carat' is used for measuring the purity of gold where pure gold is defined as 24 carats. Gold has strong "investment" attributes in all countries, and in markets such as India and Middle East is sold by weight at the prevailing daily rates. Gold is not used as currency in any market. If we include jewelers' ownership, then India is the largest repository of gold in terms of total gold within the national boundaries. Gold possesses a unique combination of properties that have resulted in its use in a wide range of industrial applications. Although the local demand as well as the fluctuations in exchange rate affects the gold market of Kathmandu, the gold prices are significantly determined by the fluctuations in international market. Fluctuations in the price of gold are driven by supply and demand including demand through speculation. The price is also affected by the policy of central banks and the International Monetary Fund, the value of the US dollar, the state of the global economy, by war, by invasion and by national emergency. Moreover, the gold-prices In Indian market also play a vital role in determining gold prices in Nepal as both the countries share open boarder. Today's gold price is affected by various factors such as demand and supply, central bank buying, inflation, geopolitics, monetary policy, equity markets, market scenarios across the globe and the strength of US dollar and more. Additionally, the price of gold differs in various cities across Nepal as well. Various factors such as taxes, demand, carriage, local associations etc. affect the gold price in different cities by Nepali Rupees 100 - 500 per tola.

\section{Conclusion and Discussion}

The present scenario of Nepali stock market is completely different from the past. Financial sectors are not well balanced. There is higher involvement of retails investors at present. The influence of big investors in past has significantly decreased as market capitalization has drastically increased. Gold price is included in the study to examine whether gold price contain any additional significant information about price movements. The investors' tendency is to switch to gold investment when they find the market to be too risky. If the country's macroeconomic indicators do not support the bull market, the market will be less durable. The political stability and secure economic situation is the key for the stock market boom.

The high level of competition and low liquidity in the banking sector has led the interest rates to rise rapidly. When banks change interest rates on deposit, they also change loan rates keeping their net interest spread almost unaltered. When interest rates changes, it's the common people who get affected. If interest rates go below the average annual return of NEPSE, there will be greater flow of capital in the stock market, which will change NEPSE's downward track to uptrend. Though gold prices and interest rates have the major impact on NEPSE, it doesn't mean to have high gold prices and low interest rate that moves NEPSE Index to bullish trend. All the non-tradable shares like promoter, government and lock in shares must be excluded while calculating index. Therefore, NEPSE Index must include floated shares only.

Reform activities such as evolution of central depository system, dematerialization of shares, supportive rules and regulations, shorter settlement time are some positive aspects of the market. The dematerialization of shares has also been successfully implemented which has shortened the settlement time. Investment of institutional investors like insurance companies, mutual fund, private equity fund etc in the stock market had also provided some strength in market. Positive things such as (Non-Resident Nepali) NRN's investment, online trading, issuance of broker license to commercial banks, increased number of mutual funds, accessibility of brokerage facility outside valley etc in near future can provide new dimension to Nepali stock market.

\section{References}

American Psychological Association. (2009). Publication manual of the American Psychological 
Association. Washington, USA: APA Service Center.

Afsal,E.M., \& Haque, M.I. (2016). Market interactions in gold and stock markets: Evidences from Saudi Arabia. International Journal of Economics and Financial Issues, Vol. 6 (3), Pp. 1025-1034.

Baskota, N.P. (2007). Stock price volatility in Nepal. Unpublished M.Phil Dissertation. Office of the Dean, Faculty of Management, Tribhuvan University.

Bhatta, G. P. (2010). Does Nepali stock market follow random walk? SEBON Journal, Vol.4, Pp.18- 58.

Chaudhuri, K., \& Koo, K. (2001). Importance of economic fundamentals. Economic and Political Weekly, Vol. $36(40)$.

Chia, R.C.J., and Lim, S.Y. (2015). Malaysian stock price and macroeconomic variables: Autoregressive distributed lag (ARDL) bounds test. Kajian Malaysia, Vol. 33 (1), 85-103.

Fama, E. F. (1981). Stock returns, real activity, inflation and money. American Economic Review, Vol. 71( 4), Pp. 545-65.

Fisher, D.E., \& Ronald, J.J. (2000). Security analysis and portfolio management. Prentice Hall Publication, New Delhi: India.

Gaire, H.N. (2018). Stock index, interest rate and gold price of Nepal: Cointegration and causality analysis. NRB Economic Review, Pp. 15-30.

Geske, R., \& Roll, R. (1983). The fiscal and monetary linkage between stock returns and inflation. The Journal of Finance, Vol. 38 (1), Pp. 1-33.

Sharma, G.D., \& Mandeep, M. (2010). Impact of macro-economic variables on stock prices in India. Global Journal of Management and Business Research. Vol. 10 (7), Pc.18

Mukhuti, S. (2018). Impact of gold prices on stock market return: An econometric analysis of BSE and NSE. International Journal of Management Studies, Vol.5 (4/7). Retrieved from; http://dx.doi. org/10.18843/ijms/v5i4(7)/01

n.d (2019). Nepal Gem and Jewellery Association (NEGJA). Retrieved online from; https://www.negja. org.np/

n.d. (2019). Federation of Nepal gold and silver dealers' association (FENEGOSIDA). Retrieved online from; http://www.fenegosida.org/

n.d. (2019). Nepal Stock Exchange Limited Annual Reports. Retrieved online from; http://www.nepalstock. $\mathrm{com} /$

OMAG, A. (2012). An observation of the relationship between gold prices and selected financial variables in Turkey. Temmuz, Pp. 195-206.

Rahman, A., \& Tafri, F.H. (2009). Macroeconomic determinants of Malaysian stock market. African Journal of Business Management, Vol. 3(3), Pp. 95-106.

Regmi, U. R. (2012). Stock market development and economic growth: Empirical evidence from Nepal. Administration and Management Review, Vol. 24(1), Pp.1-28.

Risal, N. (2016). A critical assessment on capital market development in Nepal. PRAVAHA Journal, Vol.22(1), Pp.123-129.

Risal, N. (2017). Market reaction to public information: A survey on Nepali stock market. PRAVAHA Journal, Vol..23(1), Pp. 141-157.

Risal, N., and Khatiwada, N. (2019). Herding behavior in Nepali stock market: Empirical evidences based on investors from NEPSE. NCC Journal, Vol.4 (1), Pp. 131-140.

Ross, S.A. (1976). Arbitrage theory of capital assets pricing. Journal of Economic Theory, Vol.13 (3), Pp. 341-360.

Shaique, M., Aziz, A., \& Herani, G.M. (2016). Impact of gold prices on stock exchange market: A case of Karachi Stock Exchange market of Pakistan. International Journal of Accounting and Economics Studies, Vol.4 (1), Pp. 60-63.

Shrestha, P.K., \& Subedi, B.R. (2014. Determinants of stock market performance in Nepal. NRB Economic Review, Vol. 26 (2), Pp.25-41. 
